\title{
ELASTIC CONSTANTS OF ICE BY BRILLOUIN SPECTROSCOPY
}

\author{
B) P. H. Gammon, H. Kiefte, and M. J. Clouter \\ (Department of Physics, Memorial University of Newfoundland, St John's, Newfoundland \\ $\mathrm{ArB}_{3} \mathrm{X}_{7}$, Canada)
}

\begin{abstract}
Brillouin spectroscopy has been used to measure the adiabatic elastic constants of laboratorygrown pure monocrystalline ice Ih at $-3^{\circ} \mathrm{C}$. The values obtained were (in units of $10^{8} \mathrm{~N} / \mathrm{m}^{2}$ ): $c_{11}=$ $136.96 \pm 0.60, c_{12}=69.66 \pm 0.45, c_{13}=56.28 \pm 0.31, c_{33}=147.02 \pm 0.68, c_{44}=29.59 \pm 0.15$. Comparison of these values with ultrasonic measurements quoted in the literature reveals no significant acoustic dispersion in ice over frequencies ranging to $10^{10} \mathrm{~Hz}$. However, the results suggest that the elastic constants of ice may depend on the precise crystal quality and age of a given sample. The low experimental error in the values obtained, along with the inherent versatility of the method, indicate that Brillouin spectroscopy is an effective technique for systematically investigating the elastic properties of ice samples formed under natural conditions.

RÉsumé. Les constantes élastiques de la glace par spectroscopie Brillouin. On a utilisé la spectroscopie Brillouin pour mesurer les constantes élastiques adiabatiques d'un monocristal de glace Ih pure à $-3^{\circ} \mathrm{C}$. Les valeurs obtenues ont été (en unités de $\left.10^{8} \mathrm{~N} / \mathrm{m}^{2}\right): c_{11}=136,96 \pm 0,60, c_{12}=69,66 \pm 0,45, c_{13}=56,28 \pm 0,31$, $c_{33}=147,02 \pm 0,68, c_{44}=29,59 \pm 0,15$. La comparaison entre ces valeurs avec les mesures par ultra-son rapportées dans la littérature révèlent qu'il n'y a pas de dispersion acoustique significative dans la glace pour des fréquences allant jusqu'à $10^{10} \mathrm{~Hz}$. Cependant, les résultats montrent que les constantes élastiques de la glace peuvent dépendre de la qualité précise du cristal et de l'âge d'un échantillon donné. La faible erreur expérimentale dans les valeurs obtenues, associée à la variabilité inhérente à la méthode, indique que la spectroscopie Brillouin est une technique efficace pour des investigations systématiques des propriétés élastiques des échantillons de glace formés dans les conditions naturelles.

Zusammenfassung. Elastische Konstanten des Eises aus Brillouin-Spektroskopie. Zur Messung der adiabatischen elastischen Konstanten monokristallinen Eises Ih, das im Labor hergestellt worden war, bei $-3^{\circ} \mathrm{C}$ wurde die Brillouin-Spektroskopie herangezogen. Es ergaben sich folgende Werte (in Einheiten von $10^{8} \mathrm{~N} / \mathrm{m}^{2}$ ): $c_{11}=136,96 \pm 0,60, \quad c_{12}=69,66 \pm 0,45, \quad c_{13}=56,28 \pm 0,31, \quad c_{33}=147,02 \pm 0,68, \quad c_{44}=29,59 \pm 0,15$. Der Vergleich dieser Werte mit Ultraschallmessungen, wie sie in der Literatur aufgeführt werden, weist auf keine merkliche akustische Dispersion im Eis im Frequenzbereich bis $10^{10} \mathrm{~Hz}$ hin. Doch lassen die Ergebnisse annehmen, dass die elastischen Konstanten des Eises von der genauen Kristallstruktur und vom Alter einer bestimmten Probe abhängen. Der kleine mittlere Fehler der gewonnenen Werte zeigt zusammen mit der Vielfältigkeit der Methode, dass die Brillouin-Spektroskopie ein wirksames Verfahren für systematische Untersuchungen der elastischen Eigenschaften von Eisproben, die unter natürlichen Bedingungen entstanden,
\end{abstract} ist.

\section{INTRODUCTION}

Although the rheology of ice has been a topic of considerable practical and academic interest over the years, many of the basic results are still subject to uncertainty. In part this is due to the inherently complex nature of ice, even in its pure form, but difficulty also stems from the fact that ice is a naturally occurring substance and is therefore subject to significant variations in its mode of occurrence and properties. The simplest and among the most wellstudied aspects of ice rheology is the purely elastic behaviour which occurs in the limit as a moderate stress is applied for a very short time. In ice, as in all hexagonal crystals, the elastic behaviour is concisely described by a set of five elastic moduli (Landau and Lifshits, r959), the determination of which has been the object of a series of investigations beginning with the theoretical work of Penny (1948). Subsequent experiments (Jona and Scherrer, I952; Green and Mackinnon, 1956; Bass and others, I957; Dantl, I968; Proctor, I966; for review of results see Hobbs, 1974) based primarily on ultrasonic techniques have yielded values for the elastic moduli of frozen distilled water with stated uncertainties of the order of only a few per cent. The quoted results, however, show variations larger than can be explained by probable experimental error, thus suggesting that different samples of pure ice may possess differing elastic properties. 
When extrapolating the results of laboratory experiments on controlled ice samples to engineering applications involving natural ice, it may be important to allow for variations in the purity and crystal quality of ice formed in the natural environment. That these variations might significantly affect the elastic properties of natural ice, is indicated by discrepancies in the elastic moduli of very similar artificially grown ice crystals (Dantl, 1969). No precise determination of the full set of elastic moduli for any kind of naturally formed ice can be found in the literature. To some extent, this reflects the unsuitability of conventional ultrasonic techniques, when applied to many types of natural ice samples.

The method of Brillouin spectroscopy can be used to determine acoustic wave propagation velocities and hence the adiabatic elastic moduli of transparent crystalline materials (Benedek and Fritsch, I966; Durand and Pine, I968; Stoicheff, 1973, r977; Sandercock, 1975). This technique involves the scattering of light from hypersonic (acoustic) waves which arise spontaneously from thermal excitations within a crystal. The incident light is effectively Doppler-shifted upon scattering from the propagating density fluctuations. This permits accurate spectroscopic measurement of the hypersonic acoustic velocities. In the case of a single crystal, three independent modes or frequency-shifted components (one predominately longitudinal and two predominantly transverse) are, in principle, observed. Brillouin spectroscopy does not necessitate the use of any sort of acoustic transducer and the technique

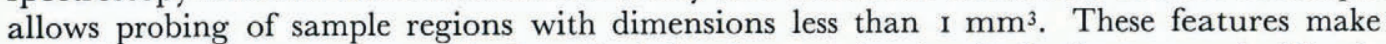
Brillouin spectroscopy a practical method for determining local elastic wave velocities in natural ice samples which may be homogeneous only over very small regions. Such a situation exists, for example, in polycrystalline ice, in lake or river ice containing numerous air bubbles, or in sea ice where brine cells and brine channels occupy spaces between crystals. In these cases one would expect acoustic wave velocities measured by conventional ultrasonic techniques to depend on the size, shape, and orientation of individual crystal grains, along with the distribution of air bubbles, brine cells, etc., within the sample. These velocity measurements would therefore not reflect the fundamental local elastic properties of the ice.

Brillouin spectroscopy has provided a practical method for determining the elastic constants of not only conventional transparent solids, but also such materials as solidified permanent gases (Stoicheff, I977; Kiefte and Clouter, I975, I976; Gammon and others, 1978) where there is significant difficulty in forming and handling monocrystalline samples, layer compounds which generally form as small flaky crystals, liquid crystals, and semiconductors (Sandercock, I975). The method has also been used to measure the temperature dependence of three of the elastic constants of ice Ih at low temperatures (Ermolieff, 1975). The results of the present application of Brillouin spectroscopy to laboratory-grown single crystals of pure ice at $-3^{\circ} \mathrm{C}$ may be used for purposes of comparison with subsequent Brillouin measurements on natural ice samples.

\section{EXPERIMENTAL TEGHNIQUE}

The small single crystals of ice required for the Brillouin scattering experiment were grown in a quartz sample cell $3 \mathrm{~mm}$ i.d., $5 \mathrm{~mm}$ o.d., and $2 \mathrm{~cm}$ long. The cell was housed in an evacuated plexiglas (polymethyl methacrylate) cylinder mounted in a bearing assembly which allowed rotation of the cell and housing about the cylindrical (vertical) axis. Heat was removed from the top and bottom of the sample cell via two brass clips which were attached with copper braids to a thermoelectric module. The temperature of the clip at the bottom of the cell was monitored with a GaAs temperature-sensing diode. The output of the diode was used to control heaters on the top and bottom clips through a feed-back circuit (Lakeshore DTC 500) which regulated the temperature at the bottom clip to well within o. I deg. Current was divided between the top and bottom heaters via an externally connected potentiometer, while a differential thermocouple indicated the temperature difference along the cell. Further 
details of the cryostat and temperature control system can be found in previous publications (Ahmad and others, I978).

The water samples used in the experiments were doubly-distilled and had a conductivity of $1.07 \times 10^{-2}(\Omega \mathrm{m})^{-1}$ and a $\mathrm{pH}$ of 5.9. The principle impurities were dissolved atmospheric gases which remained after the pressure above the sample was reduced, by pumping, to the equilibrium vapour pressure of water near the freezing point. Prior to growing a single crystal of ice, it was necessary to induce ice nucleation in the water sample. This generally required supercooling io to $20 \mathrm{deg}$ below freezing point, followed in some cases by a waiting period of a few hours. When the water in the cell solidified, invariably forming an ice sample that was not monocrystalline, the temperature was raised and the thermal gradient in the cell increased, until the ice remaining was a thin $(<0.5 \mathrm{~mm})$ layer at the bottom of the cell. This layer was then annealed (generally for at least $6 \mathrm{~h}$ ) until a visual inspection through crossed polaroids indicated that it was a single crystal. Cooling of the cell and reduction of the thermal gradient were then carried out in steps which yielded a crystal growth rate of about $2 \mathrm{~mm}$ per hour.

When a perfectly clear crystal filled the entire cell, Laue X-ray diffraction photographs were taken using a Philips (MG Ior) X-ray source, a lead collimator, and a Polaroid XR-7 Land diffraction camera. The Laue photographs were used to verify the crystal quality of the ice sample and to determine the orientation of the crystallographic axes with respect to a coordinate system (see Fig. I) fixed in the laboratory frame of reference. The orientations were calculated from the positions of spots on the Laue photograph using a program written for the HP 9825 electronic calculator.

Brillouin spectra of the ice single crystals were obtained using the optical system illustrated in Figure $\mathrm{I}$. The incident light source was a single-mode argon ion laser (Spectra Physics I65-08) using a power output of about $100 \mathrm{~mW}$ at $514.5 \mathrm{~nm}$. The scattered light was analysed with a piezoelectrically scanned triple-pass Fabry-Perot interferometer utilizing $\lambda / 200$,

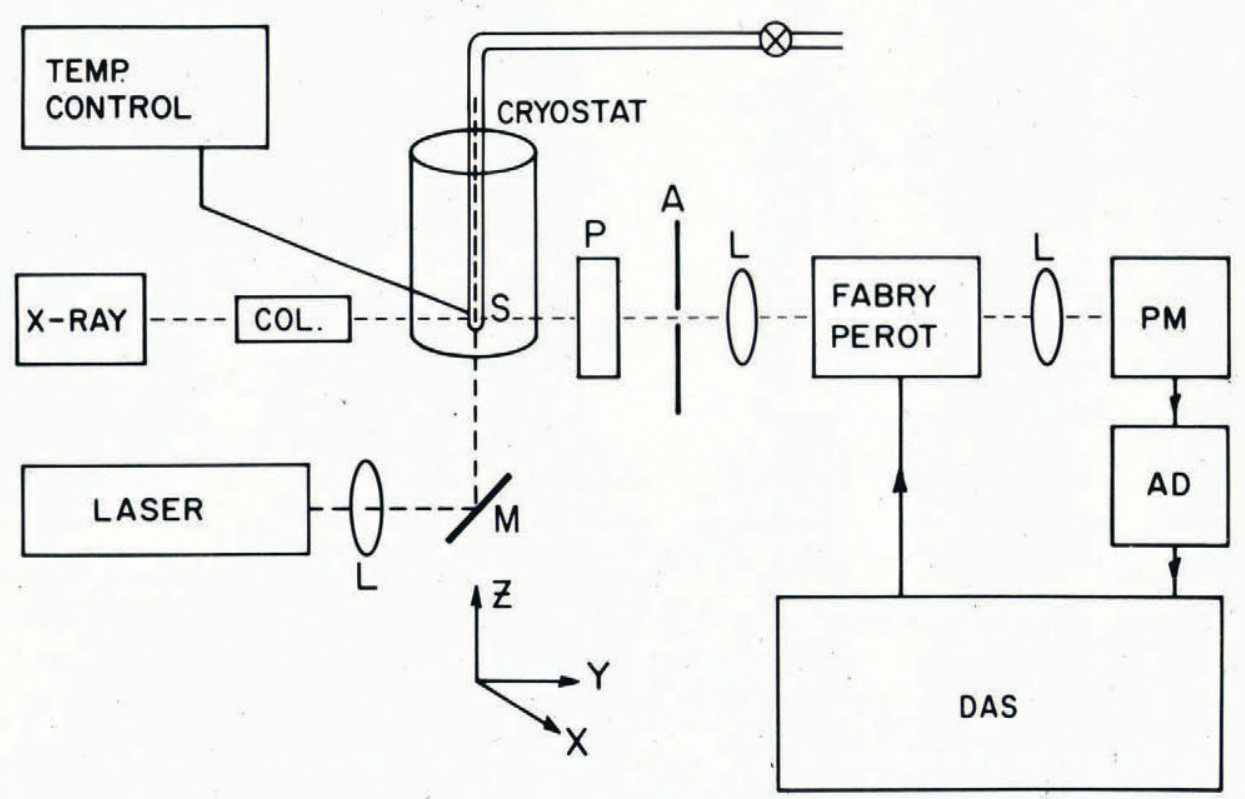

Fig. I. Experimental set-up. S-Sample cell; P-Polaroid X-ray camera; A-Aperature; M-Mirrors; L-Lenses; $P M-$ Photomultiplier; AD-Amplifier discriminator; DAS-Data acquisition and stabilization system. 
$93 \%$ reflectivity plates (Burleigh Instruments Inc.) and detected with a cooled photomultiplier tube (ITT FWI30). The output from the photomultiplier was coupled through an amplifier discriminator (PAR I I 20) to a data aquisition and stabilization system (Burleigh DAS I), which in turn provided the ramp voltage used in scanning the Fabry-Perot interferometer. The multi-channel analyser (MCA) of the DAS system accumulated spectral data in the form of photon counts (intensity) versus MCA channel number (proportional to the FabryPerot plate separation and hence to the frequency of the scattered light). Additionally, the DAS system utilized negative feed-back circuitry to compensate for drift in the optical system, including Fabry-Perot misalignment, thereby allowing arbitrarily long spectral accumulation times (Gammon and others, I978).

Brillouin spectra were recorded for each of several orientations of four ice single crystals. The different orientations of a given crystal were obtained by rotating the cell about the cryostat axis. Since the directional dependence of sound-wave velocities in a hexagonal crystal, involves only the angle $\gamma$ between the wavevector and the crystal $c$-axis (Landau and Lifshits, 1959), efforts were made to obtain data well distributed over the full $\left(0^{\circ}-90^{\circ}\right)$ range of $\gamma$ values. This necessitated using the known orientation of a crystal to calculate, and thereby select, an appropriate angle of rotation for the cell prior to running each Brillouin spectrum. Usually, spectra were accumulated for sufficient time periods to allow clear resolution of the longitudinal and at least one transverse Brillouin component. These time periods averaged about $6 \mathrm{~h}$, although some spectra were accumulated for periods exceeding $24 \mathrm{~h}$. A typical Brillouin spectrum showing. all three acoustic components is shown in Figure 2.

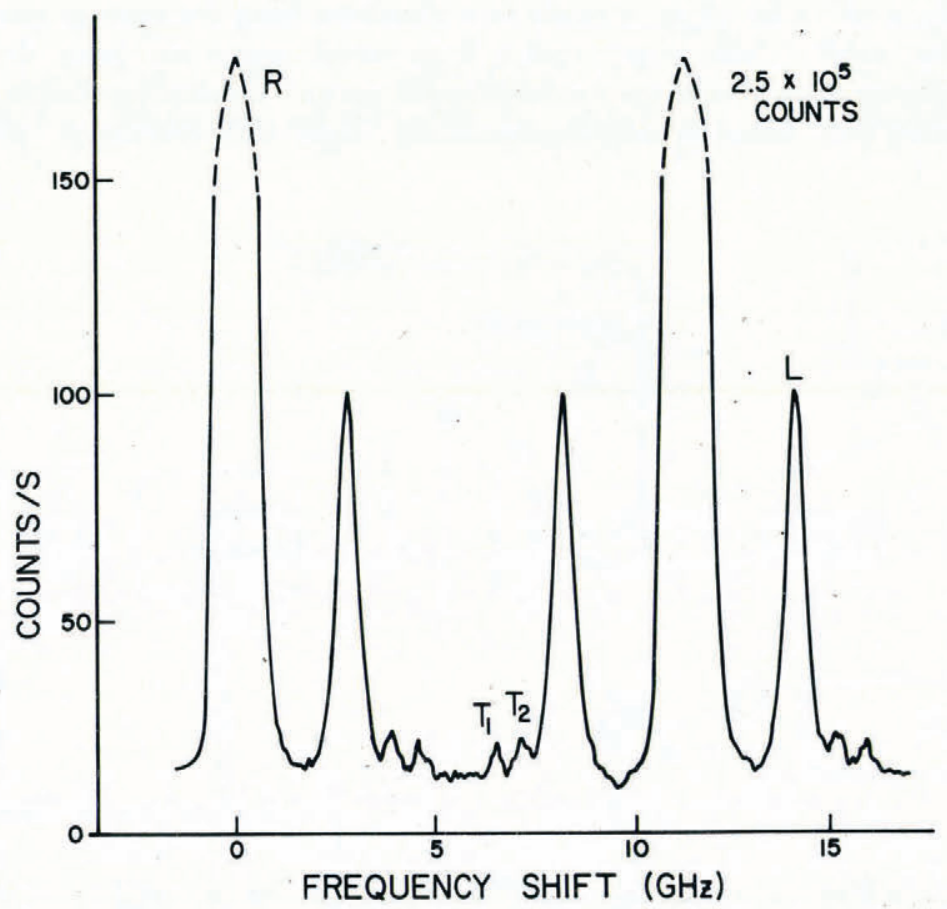

Fig. 2. $A_{3} h$ Brillouin spectrum from crystal $B$ at $\gamma=24 \cdot 9^{\circ}$. One and a half overlapping orders are shown, with two central components. $L$ designates the longitudinal Brillouin component and $T_{1}$ and $T_{2}$ the transverse components as shifted from central component $R$. The width of the central component represents the instrumental line width and was about $200 \mathrm{MHz}$. The transverse components ranged in width from 200 to $300 \mathrm{MHz}$ and the longitudinal components from 400 to $600 . \mathrm{MHz}$, depending on crystal orientation. A total time of 10 s was spent accumulating counts in each MCA channel. 


\section{Results AND ANALysis}

The 30 Brillouin spectra obtained during the course of this experiment yielded 65 experimental data points. The raw spectral data were taken in digital form from the cathode ray tube of the DAS multichannel analyser and consisted of frequency shifts (measured in channel numbers) corresponding to the peaks of the respective Brillouin components. The number of channels separating two adjacent orders of the unshifted laser line corresponded to a reference frequency referred to as the free spectral range. The magnitude of the free spectral range, I I.IOI GHz, was determined from a precise measurement of the plate separation (0.013 $503 \mathrm{~m}$ ) of the Fabry-Perot interferometer. The measured Brillouin frequency shifts $\Omega$ were related to acoustic wave velocities $V$ by the Brillouin equation, $V=\Omega \lambda / 2 n \sin (\alpha / 2)$ (Benedek and Fritsch, I 966), $\lambda$ being the wavelength of the incident laser radiation, $n$ the refractive index of the sample, and $\alpha$ the angle between the propagation directions of the incident and scattered laser radiation. The equations used to relate sound velocity to the density and elastic moduli of ice are given by Musgrave (1970). These equations were inverted with the aid of a computer-programmed least-squares fit procedure thereby yielding values for the elastic constants.

The complete set of input data consisted of the frequency shift measurements listed in Table I, along with values for the density of ice $\rho$ and the parameters $\lambda, n$, and $\alpha$ appearing in the Brillouin equation. The laser wavelength $\lambda$ was $5.145 \times 10^{-7} \mathrm{~m}$ with negligible

Table I. Summary of experimental data

\begin{tabular}{|c|c|c|c|c|c|c|c|}
\hline \multicolumn{5}{|c|}{$\begin{array}{c}\text { Euler angles* specifying crystal } \\
\text { orientation }\end{array}$} & \multicolumn{3}{|c|}{$\begin{array}{l}\text { Brillouin frequency shifts }(\Omega) \\
\text { in } \mathrm{GHz}\end{array}$} \\
\hline Crystal & $\phi$ & $\theta$ & $\psi$ & $\gamma$ & $L$ & $T_{\mathrm{I}}$ & $T_{2}$ \\
\hline \multirow[t]{15}{*}{ A } & 60.7 & 67.9 & 81.5 & $54 \cdot 1$ & 13.49 & - & - \\
\hline & $79 \cdot 5$ & 68. I & $8 \mathrm{r} . \mathrm{I}$ & 67.5 & 13.68 & - & 7.27 \\
\hline & 38.9 & 68.5 & 81.2 & 39.5 & 13.62 & 6.62 & - \\
\hline & 13.8 & 68.5 & 81.8 & 26. I & 13.74 & 6.49 & 7.24 \\
\hline & 106.4 & 68.0 & 81.2 & 85.4 & 14.00 & - & 6.60 \\
\hline & 93.8 & 67.7 & 81.0 & 77.0 & I 3.68 & - & 6.76 \\
\hline & 48.7 & 68.2 & 81.6 & 45.9 & 13.34 & - & - \\
\hline & 28.5 & 68.0 & 82.3 & 32.7 & 13.71 & 6.56 & - \\
\hline & $3 \cdot 5$ & 68.7 & 82.0 & 23.9 & 14.08 & $6.5^{6}$ & - \\
\hline & 84.9 & 67.4 & $8 \mathrm{I}, \mathrm{I}$ & 70.7 & 13.86 & - & 7.04 \\
\hline & 72.8 & $67 \cdot 3$ & 8 ז.8 & 62.2 & 13.73 & - & $7 \cdot 40$ \\
\hline & 54.6 & 67.9 & 81.7 & 49.8 & I $3.5^{6}$ & - & - \\
\hline & 43.5 & 68.0 & 82.0 & $4^{2.2}$ & 1 3.56 & - & - \\
\hline & 21.6 & 68.2 & 82.1 & 29.2 & $13.9^{2}$ & $6.6 \mathrm{I}$ & 7.55 \\
\hline & 105.2 & 68.0 & 81.0 & 84.7 & I 3.80 & - & 6.46 \\
\hline \multirow[t]{5}{*}{ B } & 197.3 & 114.4 & 247.0 & 24.9 & 13.98 & 6.52 & 7.19 \\
\hline & 223.5 & I 14.7 & 247.9 & 40.4 & I 3.59 & 6.64 & 7.75 \\
\hline & 248.4 & I I 5.0 & 248.0 & 57.7 & $13.5^{2}$ & - & $7 \cdot 5^{6}$ \\
\hline & 258.0 & II 5.1 & 248.2 & $64 \cdot 3$ & I 3.64 & - & 7.25 \\
\hline & 275.5 & I I 5.3 & 248.7 & 76.1 & $\mathrm{I} 3.8 \mathrm{I}$ & - & 6.77 \\
\hline \multirow[t]{6}{*}{ C } & 3.8 & $5^{8.9}$ & 248.9 & 14.2 & 14.25 & $6.5^{2}$ & - \\
\hline & I 9.6 & 58.5 & 249.0 & 20.4 & 14.14 & 6.54 & 7.03 \\
\hline & 42.0 & 58.0 & 248.4 & 34.9 & 13.70 & - & $7.6 \mathrm{I}$ \\
\hline & 53.7 & 57.8 & 248.4 & 43.1 & I $3.5^{8}$ & - & 7.85 \\
\hline & 67.9 & 57.6 & 248.1 & $5^{2.9}$ & $13.5 \mathrm{I}$ & 6.79 & 7.69 \\
\hline & $79 \cdot 9$ & 57.6 & 247.5 & 6I.I & $13.6 \mathrm{I}$ & $6.8 \mathrm{I}$ & $7 \cdot 37$ \\
\hline \multirow[t]{4}{*}{ D } & 277.8 & 98. I & 91.8 & 89.7 & $13.9 \mathrm{I}$ & - & 6.46 \\
\hline & 277.8 & 98. I & $9^{1} .8$ & 89.7 & $13.9^{2}$ & - & 6.46 \\
\hline & 287.6 & $9^{8.8}$ & 92.0 & 84.1 & 13.90 & 6.90 & 6.53 \\
\hline & 316.6 & $9^{8.9}$ & $9^{2.3}$ & 66.5 & 13.64 & 6.83 & 7.21 \\
\hline
\end{tabular}

* Euler angles $\phi, \theta, \psi$ specify an ordered sequence of rotations about the $z, x^{\prime}, z^{\prime \prime}$ axes respectively. See Goldstein ([$\left.\left.{ }^{{ }^{1}}{ }_{1950}\right]\right)$. 
uncertainty. The scattering angle $\alpha$ was established by the alignment of the optical system and was set at $90^{\circ}$ with an estimated uncertainty of $\pm 0.2^{\circ}$. The refractive index $n$ of ice at $-3^{\circ} \mathrm{C}$ for light of wavelength $5.145 \times 1 \mathrm{IO}^{-7} \mathrm{~m}$ was determined by linear interpolation from values given in the International critical tables (1926-33). The index was taken to be $n=1.312 \pm 0.001$, where the uncertainty is included primarily to account for the slight birefringence $\left(n^{0}=\mathrm{I} .3^{\mathrm{II}} 7 \pm 0.0003, n^{\mathrm{e}}=1.3^{\mathrm{I}} 3 \mathrm{I} \pm 0.0003\right)$ of hexagonal ice.

The density $\rho$ of ice at $-3^{\circ} \mathrm{C}$ was estimated to be $917.5 \pm 1.5 \mathrm{~kg} / \mathrm{m}^{3}$, based on several values given in the literature. These values appear to show some dependence on the purity, age, and crystal quality of a given sample and on the method of measurement. A review of ice density measurements prior to 1940 , along with a comment on their variability, can be found in the text by Dorsey (1940). The density value quoted in the International critical tables ( $1926-33$ ) for ice at $o^{\circ} \mathrm{C}, \mathrm{I}$ atm, is $916.8 \pm 0.5 \mathrm{~kg} / \mathrm{m}^{3}$. An experiment utilizing the Bunsen Ice Calorimeter yielded a value of $9 \mathrm{I} 6.7 \mathrm{I} \pm 0.05 \mathrm{~kg} / \mathrm{m}^{3}$ for the density of freshly formed polycrystalline ice at $0^{\circ} \mathrm{C}$ (Ginnings and Corruccini, 1947). Specific gravity measurements (by immersion in 2,2,4-trimethylpentane) on several high-quality monocrystals of pure ice from the Mendenhall Glacier gave an average value of $917.18 \mathrm{~kg} / \mathrm{m}^{3}$ for the density at $-3.5^{\circ} \mathrm{C}$ (Butkovich, 1955). An X-ray crystallographic determination of the lattice parameters of tiny ice crystals frozen from droplets of distilled water (LaPlaca and Post, i96o), implied a density of $918.7 \mathrm{~kg} / \mathrm{m}^{3}$ at $-10^{\circ} \mathrm{C}$. To form Table II, each of the four density values referred to above was corrected to the value appropriate for $-3^{\circ} \mathrm{C}$ using the thermal expansion data of Butkovich (1959). The r.6\% uncertainty allowed in the density of ice, for purposes of the present analysis, reflects the variability in density from sample to sample noted by several of the above mentioned authors and by Dantl and Gregora (1968), who show that the density tends to decrease with sample age.

TABLe II. Four determinations of THE Density of ICE Ih

\begin{tabular}{lcl}
\multicolumn{1}{c}{ Source } & $\begin{array}{c}\text { Density }\left(-3^{\circ} \mathrm{C}\right) \\
\mathrm{kg} / \mathrm{m}^{3}\end{array}$ & \multicolumn{1}{c}{ Reference } \\
& & \\
Critical examination of available data & 917.2 & International critical tables (1926-33) \\
Bunsen ice calorimeter & 917.14 & Ginnings and Corruccini (1947) \\
Mendenhall Glacier & $917.1 \mathrm{I}$ & Butkovich (1955) \\
X-ray crystallography & 917.7 & LaPlaca and Post (1960)
\end{tabular}

To facilitate error analysis, the sources of uncertainty in the elastic constants were divided into two categories. The first category included the systematic error terms, common to all five elastic constants, resulting from uncertainty in the values of $\lambda, \alpha, n$, and $\rho$. The combined uncertainty in these quantities was calculated to be $0.4 \%$. Secondly, a random error term resulted from uncertainty in the Brillouin frequency-shift measurements and in the orientations of the ice crystals. This error was estimated empirically from the scatter of the sound velocity data about the curves of $V$ versus $\gamma$ (see Fig. 3) specified by hexagonal symmetry. The empirical error calculation was included in the least-squares fit routine used to calculate the elastic constants. This routine also determined an empirical estimate for the standard deviation of the Brillouin frequency-shift measurements. Separate standard-deviation values were calculated for the frequency-shift data obtained from the first ice crystal and for that obtained from the subsequent three crystals. This was necessary because of the gradual accumulation of a light film of precipitated vacuum oil on the outside of the sample cell. This film caused distortion in the optics and hence significantly decreased resolution in the Brillouin spectra obtained from the first crystal (A). Removal of the oil film reduced scatter and consequently reduced the empirical standard deviation in data obtained from the subsequent three crystals by a factor of 3.5. This factor was used to down-weight the data from the first crystal when making the final determination of the elastic constants. 


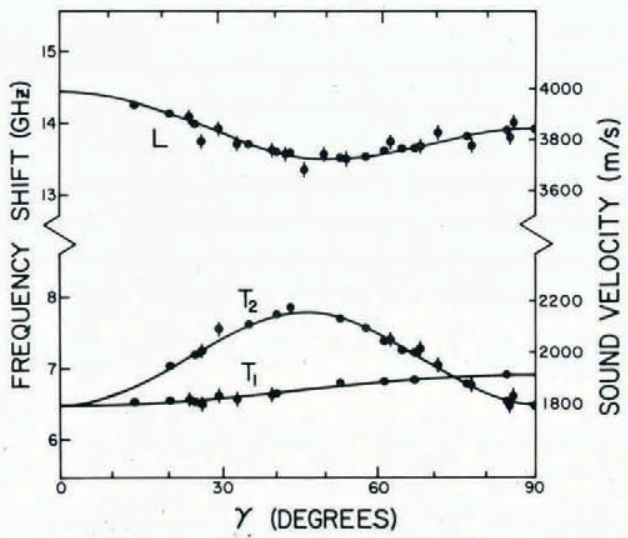

Fig. 3. Measured acoustic velocities (indicated by the solid dots) as determined from the Brillouin frequency shifts, and calculated velocities (indicated by the solid curves) for ice Ih at $-3^{\circ} \mathrm{C}$ versus the angle $\gamma$ between the crystal hexagonal axis and the direction of sound propagation. The standard deviation in the measured frequency shifts is about half the radius of the dots or, for data from crystal $A$, is indicated by the vertical bars.

The resulting values for the adiabatic elastic moduli of ice $\mathrm{Ih}$ at $-3{ }^{\circ} \mathrm{C}$, are listed below. The error has been divided into its systematic and random components.

$$
\left.\begin{array}{l}
c_{11}=136.96 \pm 0.15 \% \\
c_{12}=69.66 \pm 0.50 \% \\
c_{13}=56.28 \pm 0.37 \% \\
c_{33}=147.02 \pm 0.20 \% \\
c_{44}=29.59 \pm 0.30 \%
\end{array}\right\} \times\left(\mathrm{ro}^{8} \pm 0.4 \%\right) \mathrm{N} / \mathrm{m}^{2} .
$$

Figure 3 shows the complete set of experimental data points, along with the least-squares curves of $\Omega$ and $V$ versus $\gamma$ for the three acoustic modes.

\section{Discussion}

The present results, along with the results of three previous experimental determinations of the full set of elastic moduli of ice Ih, are summarized in Table III. The tabulated values for the $c_{i j}$ 's have been adjusted to correspond to a temperature of $-3^{\circ} \mathrm{C}$, using the linear temperature-correction factors determined by Dantl (1968). The good general agreement

\begin{tabular}{|c|c|c|c|c|}
\hline \multirow{2}{*}{$\begin{array}{c}\text { Authors } \\
\text { Method of measuremen }\end{array}$} & Jona and Scherrer (1952) & Bass and others ( 1957 ) & Dantl ( 1968$)$ & Present \\
\hline & $\begin{array}{l}\text { Schafer-Bergmann } \\
\text { method }\end{array}$ & $\begin{array}{l}\text { Resonant bars and } \\
\text { plates }\end{array}$ & $\begin{array}{l}\text { Ultrasonic pulse-echo } \\
\text { and double-pulse } \\
\text { interference }\end{array}$ & $\begin{array}{l}\text { Brillouin } \\
\text { spectroscopy }\end{array}$ \\
\hline $\begin{array}{c}\text { Temperature of sample } \\
\text { Frequency }\end{array}$ & $\begin{array}{l}-16^{\circ} \mathrm{C} \\
{ }_{15} \mathrm{MHz}-18 \mathrm{MHz}\end{array}$ & $\begin{array}{l}-2^{\circ} \mathrm{C} \text { to }-30^{\circ} \mathrm{C} \\
5 \mathrm{kHz}-50 \mathrm{kHz}\end{array}$ & $\begin{array}{l}0^{\circ} \mathrm{C} \text { to }-140^{\circ} \mathrm{C} \\
5 \mathrm{MHz}-190 \mathrm{MHz}\end{array}$ & $\begin{array}{l}-3^{\circ} \mathrm{C} \\
10 \mathrm{GHz}\end{array}$ \\
\hline $\begin{array}{l}\text { Adiabatic elastic } \\
\quad \text { moduli } \\
\text { corrected to } \\
-3^{\circ} \mathrm{C} \\
\left(10^{8} \mathrm{~N} / \mathrm{m}^{2}\right)\end{array}$ & $\begin{array}{r}135.8 \pm 0.8 \\
68.8 \pm 1.2 \\
56.7 \pm 1.6 \\
146.7 \pm 0.8 \\
31.2 \pm 0.3\end{array}$ & $\begin{array}{l}130 \pm 8 \\
61 \pm 8 \\
45 \pm 9 \\
139 \pm 7 \\
30.0 \pm 0.15\end{array}$ & $\begin{array}{r}129.6 \pm 0.4 \\
65.3 \pm 1.3 \\
56.5 \pm 4.0 \\
141.4 \pm 0.6 \\
28.3 \pm 0.2\end{array}$ & $\begin{array}{r}136.96 \pm 0.60 \\
69.66 \pm 0.45 \\
56.28 \pm 0.31 \\
147.02 \pm 0.68 \\
29.59 \pm 0.15\end{array}$ \\
\hline
\end{tabular}
among the four sets of results indicates a lack of significant acoustic dispersion in ice over the frequency range $1^{4} \mathrm{~Hz}$ to $\mathrm{IO}^{10} \mathrm{~Hz}$. This in turn suggests that elastic moduli determined by Brillouin spectroscopy can be related to the quasi-static elastic behaviour of ice. In this

TABle III. Measurements of the elastic moduli of ICE Ih 
respect, the Brillouin spectroscopic results can be applied with equal reliability as can results obtained by any other dynamic method of measurement.

The agreement of the present results with those of Jona and Scherrer (1952) is within experimental uncertainty for all elastic constants except $c_{44}$, in which there is only a slight discrepancy. However, the elastic moduli measured by Dantl (1968) average about $4 \%$ lower than the present results. These comparisons seem to support the hypothesis, suggested by Dantl (1969), that the elastic moduli of ice increase with density and consequently decrease with the age of the given sample. The ice samples used by Dantl were aged for eight months prior to determination of their elastic moduli. In contrast, the samples used in the present experiment, and also presumably in the experiment by Jona and Scherrer, were not aged appreciably.

Brillouin spectroscopy has been demonstrated to be an effective technique for studying the elastic properties of ice monocrystals grown in the laboratory. The optical imperfections in naturally formed ice samples would tend to make accurate determination of their elastic moduli by Brillouin spectroscopy somewhat more difficult. However, there appear to be very few instances in which the method would be totally inapplicable. Particularly good results can be expected from experiments on clear glacial ice or on lake or river ice containing clear monocrystalline regions of greater than millimetre dimensions. In these cases, measurements of the elastic moduli by Brillouin spectroscopy could be made to possess uncertainties comparable to those obtained in the present experiment. Even very small variations in the elastic properties of the samples would thus be noted. In sea ice, highly irregular crystal grain structure and poor optical quality would make Brillouin measurements considerably less precise. Nevertheless, deviation of more than a few per cent in the elastic properties relative to those of fresh-water ice should be detectable. Brillouin scattering experiments on several types of natural ice, including sea ice, are currently in progress at this laboratory.

\section{Acknowledgements}

The assistance of Mr S. F. Ahmad in building the cryostat, and of Mr B. L. Whiffen in helping to set up the experiment and to analyse the data, is appreciated. Helpful discussions with Dr W. W. Denner are also gratefully acknowledged.

MS. received I4 May 1979 and in revised form I August 1979

\section{REFERENCES}

Ahmad, S. F., and others. 1978. Brillouin scattering in single crystals of plastic cyclohexane, by S. F. Ahmad, H. Kiefte, and M. J. Clouter. Fournal of Chemical Physics, Vol. 69, No. 12, p. 5468-72.

Bass, R., and others. 1957. Die elastischen Konstanten des Eises, [by] R. Bass, D. Rossberg, G. Ziegler. Zeitschrift für Physik, Bd. 149, Ht. 2, p. 199-203.

Benedek, G. B., and Fritsch, K. I966. Brillouin scattering in cubic crystals. Physical Review, Vol. 149, No. 2, p. $647-62$.

Butkovich, T. R. 1955. Density of single crystals of ice from a temperate glacier. Fournal of Glaciology, Vol. 2, No. 18, p. 553-59.

Butkovich, T. R. I959. Thermal expansion of ice. Journal of Applied Physics, Vol. 30, No. 3, p. $350-53$.

Dantl, G. 1968. Die elastischen Moduln von Eis-Einkristallen. Physik der kondensierten Materie, Bd. 7, Ht. 5, p. $390-97$.

Dantl, G. 1969. Elastic moduli of ice. (In Riehl, N., and others, ed. Physics of ice: proceedings of the international symposium on physics of ice, Munich, Germany, September $9^{-1} 4,1968$. Edited by $\mathcal{N}$. Riehl, B. Bullemer, H. Engelhardt. New York, Plenum Press, p. 223-30.)

Dantl, G., and Gregora, I. I968. Dichte in hexagonalem Eis. Naturwissenschaften, Bd. 55, Ht. 4, p. 176.

Dorsey, N. E. 1940. Properties of ordinary water-substance in all its phases: water-vapor, water, and all the ices. New York, Reinhold Publishing Corporation. (American Chemical Society. Monograph Series, No. 81.) 
Durand, G. E., and Pine, A. S. 1968. High-resolution low-level Brillouin spectroscopy in solids. IEEE Journal of Quantum Electronics, Vol. QE-4, No. 9, p. 523-28.

Ermolieff, A. 1975. Brillouin scattering in ice and deuterated ice as a function of temperature. Solid State Communications, Vol. 17, No. 8, p. 1013-16.

Gammon, P. H., and others. 1978. Brillouin scattering in single crystals of $\beta$-carbon monoxide: determination of the elastic constants at the triple point, by P. H. Gammon, H. Kiefte, and M. J. Clouter. Fournal of Chemical Physics, Vol. 70, No. 2, p. 810-15.

Ginnings, D. C., and Corruccini, R. J. 1947. An improved ice calorimeter - the determination of its calibration factor and the density of ice at $0^{\circ} \mathrm{C}$. Fournal of Research of the National Bureau of Standards, Vol. 38, No. 6, Research Paper RPi 796, p. 583-91.

Goldstein, H. [' ${ }^{\mathrm{I}}$ 950.] Classical mechanics. Reading, Mass., Addison-Wesley Publishing Co., Inc. (AddisonWesley Series in Advanced Physics.)

Green, R. E., $j r$, and Mackinnon, L. 1956. Determination of the elastic constants of ice single crystals by an ultrasonic pulse method. Fournal of the Acoustical Society of America, Vol. 28, No. 6, p. 1292.

Hobbs, P. V. 1974. Ice physics. Oxford, Clarendon Press.

International critical tables. I926-33. International critical tables. New York and London, McGraw-Hill Book Co., Inc. 8 vols.

Jona, F., and Scherrer, P. 1952. Die elastischen Konstanten von Eis-Einkristallen. Helvetica Physica Acta, Vol. 25, Fasc. 1-2, p. 35-54.

Kiefte, H., and Clouter, M. J. 1975. Brillouin scattering in single crystals of $\gamma$-oxygen: determination of the elastic constants at the triple point. Journal of Chemical Physics, Vol. 62, No. 12, p. $4780-86$.

Kiefte, H., and Clouter, M. J. I976. Brillouin scattering in single crystals of $\beta$-nitrogen: determination of the elastic constants at the triple point. Fournal of Chemical Physics, Vol. 64, No. 4, p. 1816-19.

Landau, L. D., and Lifshits, Ye. M. 1959. Theory of elasticity. Translated from the Russian by F. B. Sykes and W. H. Reid. London, Pergamon Press. (Course of Theoretical Physics, Vol. 7.)

LaPlaca, S. J., and Post, B. I96o. Thermal expansion of ice. Acta Crystallographica, Vol. 13, Pt. 6, p. 503-05.

Musgrave, M. J. P. 1970. Crystal acoustics. San Francisco, Holden-Day.

Penny, A. H. A. 1948. A theoretical determination of the elastic constants of ice. Proceedings of the Cambridge Philosophical Society, Vol. 44, Pt. 3, p. 423-39.

Proctor, T. M., jr. 1966. Low-temperature speed of sound in single-crystal ice. Fournal of the Acoustical Society of America, Vol. 39, No. 5, Pt. I, p. $972-77$.

Sandercock, J. R. I 975 . Some recent developments in Brillouin scattering. RCA Review, Vol. 36, No. 1, p. 89-107.

Stoicheff, B. P. r973. Brillouin and Raman spectroscopy with lasers. (In Feld, M. S., and others, ed. Fundamental and applied laser physics. Proceedings of the Esfahan symposium, August 29 to September 5, 1971. Edited by M. S. Feld, A. Favan, and $\mathcal{N}$. A. Kurnit. New York, John Wiley and Sons, Inc., p. 573-61 1.)

Stoicheff, B. P. 1977. Brillouin spectroscopy and elastic constants. (In Klein, M. L., and Venables, J. A., ed. Rare gas solids. Vol. 2. New York, Academic Press, p. 979-1020.) 